\title{
Multiple Myeloma Presenting as a Left Clavicular Swelling - A Case Report
}

\author{
Dilbag Singh ${ }^{1 *}$, Harveen Kaur ${ }^{1}$ and Naveen Pandhi ${ }^{2}$ \\ ${ }_{1}^{1}$ Junior resident, Department of Pulmonary Medicine, Government Medical College, Amritsar, Punjab, India \\ ${ }^{2}$ Professor and Head, Department of Pulmonary Medicine, Government Medical College, Amritsar, Punjab, India
}

Submission: June 11, 2021; Published: June 22, 2021

*Corresponding author: Dilbag Singh, Junior resident, Department of Pulmonary Medicine, Government Medical College, Amritsar, Punjab, India

\begin{abstract}
Clavicular swellings constitute an important underdiagnosed entity in clinics. The reason for this includes mild nature of symptoms and thus less emphasis given to them by the patient as well as treating physician. It is important to do thorough examination and early investigations as this may point towards the diagnosis of a specific inflammatory, infectious, or neoplastic disorder. Moreover, in countries with a very high burden of tuberculosis (TB) like India, it becomes pivotal to first rule out extrapulmonary lymph node TB. Also, the failure to recognize and treat the specific condition can significantly add up to the morbidity and the resultant mortality. Clavicular swelling or fractures can occasionally be a presentation of solitary plasmacytomas but, multiple myeloma involving clavicle is extremely rare. 10-40\% cases of multiple myeloma are asymptomatic and incidentally detected. We present a case of 57 years old female with a left clavicular swelling, which was examined and diagnosed as multiple myeloma.
\end{abstract}

Keywords: Multiple myeloma, clavicular swelling, serum protein electrophoresis, MRI Neck, USG Neck, bone marrow biopsy, PET-CT

\section{Introduction}

Clavicular swellings can be caused by several pathological conditions including infections, inflammation, tumours, or metastasis. In countries like India, carrying a high burden of TB, extrapulmonary lymph node TB is to be ruled out first. The primary tumours of the clavicle include malignant adamantinoma and benign enchondroma. Metastasis can be found in patients with bronchogenic carcinoma or renal cell carcinoma. Although, metastasis is much more common than a primary bone tumour. Sternoclavicular joint involvement is also seen in cases of osteoarticular tuberculosis. It can even be a presentation of solitary plasmacytoma and in very rare cases of multiple myeloma.

Multiple myeloma, also known as Kahler's disease, is an allied malignancy of reticuloendothelial cells. It is a relatively rare disease, occurring mainly in individuals over 60 years of age [1]. This malignant plasma cell proliferation mainly affects the bone marrow and skeletal system. It is a neoplasm of terminally differentiated plasma cells, clonal B-lymphocyte proliferation. It accounts for $1 \%$ of all malignancies and $10 \%$ of hematologic malignancies. The annual incidence is 3 to 4 per 100,000 populations per year, with about 14,000 new cases each year. $10-40 \%$ multiple myeloma cases are incidental diagnoses. The median age at diagnosis is around 60 years and only about $3 \%$ patients are younger than 40 years. Higher incidence of this disease is in men and African Americans.

Though the exact aetiology is unknown, radiation exposure can act as a contributing factor. Gene-sequencing studies imply its origin from a late cell in B-cell development. Bone involvement secondary to bone marrow infiltration is the most common manifestation, resulting in osteolytic lesions, bone pains, and pathological fractures. Increased proliferation and survival of osteoclasts leads to bone resorption [2]. This rare entity and its atypical presentation often leads to misdiagnosis and mismanagement which further adds on to complications. We present here the case of an unsuspected patient whose initial presentation of multiple myeloma was a left clavicular swelling.

\section{Case Report}

A 57-year-old female came with chief complaint of a swelling in the left clavicular region from past 1 year, which gradually became slightly painful, bringing the patient to the outpatient 


\section{Cancer Therapy \& Oncology International Journal}

department. It raised the suspicion of inflammation, infections, trauma, primary bone/cartilage tumour, and metastasis. Detailed history was obtained from the patient. There was no history of fever, weight loss, or discharge from swelling or any other swelling elsewhere and there was no history suggestive of contact with a tuberculosis patient or any previous head and neck surgery.

On examination she was pale. There was no lymphadenopathy. She had a globular, smooth swelling of around $4.5 \times 4 \mathrm{~cm}$ in the left medial end of clavicle. It was non-tender, soft to firm and not adhering to skin and fixed to underlying bone. Skin over swelling was normal. Rest of her systemic examination was normal.

Baseline investigations were performed. She had a normochromic anaemia with a borderline leucopenia ( $\mathrm{Hb} 8.4$ g/l, TLC $3768 / \mathrm{mm} 3$ and a raised ESR of $90 \mathrm{~mm} / \mathrm{hr}$ ). Sputum for AFB was negative and sputum for CBNAAT did not detect Mycobacterium tuberculosis. TST was non-reactive, thus ruling out the possibility of tuberculosis.

Patient was hypercalcaemic (corrected calcium levels 3.24 $\mathrm{mmol} / \mathrm{l}$, phosphate $1.76 \mathrm{mmol} / \mathrm{l}$, alkaline phosphatase $114 \mathrm{U} / \mathrm{l}$ ) with AST $54 \mathrm{U} / \mathrm{l}$ and normal serum bilirubin levels, along with $9.37 \mathrm{~g} / \mathrm{dL}$ total proteins. 25(OH)D3 levels were $80.0 \mathrm{ng} / \mathrm{ml}$. Urine protein (quantitative) revealed levels of $380.0 \mathrm{mg} / \mathrm{TV}$. Renal function tests were within normal limits. Plain radiograph of left clavicle showed expansile, lytic lesion in the medial aspect with no evidence of pathological fracture or periosteal reaction. USG neck showed a large, irregular, heterogenous, destructive lesion in left side of neck in relation to bony shadow of medial aspect of left clavicle, measuring $45.5 \times 40.1 \times 36.7 \mathrm{~mm}$ in size. MRI neck revealed an expansile lytic lesion in the medial end of left clavicle, along with micronodular and diffuse pattern of skeletal involvement, suggestive of malignancy and was advised biopsy correlation.

Bone marrow biopsy taken from posterior superior iliac spine revealed the slightly hypercellular marrow with increase in plasma cells about 14\%, raising the suspicion of plasmacytoma. PET-CT revealed FDG avid expansile lytic sclerotic lesion with soft tissue component, involving the medial end of left clavicle (SUV max 6.3, 5.9x5.1x5.8cm) and causing cortical erosion with destruction, along with few focal areas of necrosis. Lesion abutting the left internal jugular vein, left brachiocephalic vein, and also attenuating the left suprascapular artery. Variably FDG avid multiple lytic lesions noted in skull, bilateral mandible, head of right humerus, sternum, multiple cervico-dorso-lumbar vertebrae, few bilateral lesions (right posterior $10^{\text {th }}$ rib-SUVmax 5.7), with fractures, sacrum (right ala-SUVmax 6.0), multiple sites in bilateral pelvic bones.

Serum Beta-2-microglobulin levels were $2764 \mathrm{ng} / \mathrm{ml}$. Serum protein electrophoresis was performed, the quantitative immunofixation showed: Total proteins $8.7 \mathrm{~g} / \mathrm{dl}$ with Beta 2 globulin levels of $0.58 \mathrm{~g} / \mathrm{dl}$ and Gamma globulin $2.18 \mathrm{~g} / \mathrm{dl}$; and the qualitative immunofixation revealed the presence of IgG Lambda and M-band in the gamma region in the background of marked hypogammaglobulinemia, M-spike $-1.21 \mathrm{~g} / \mathrm{dL}$. Serum free Lambda levels were $618 \mathrm{mg} / \mathrm{l}$ with free Kappa/Lambda ratio being 0.03 , reflecting the increased production of free monoclonal light chains. Then, a Bone marrow biopsy of the mass was done, and the aspirate showed approximately $1.6 \%$ plasma cells, out of which approx. 95\% were Lamba light chain restricted clonal plasma cells showing multiple surface marker expression abnormalities. Fluorescent microscopy of bone marrow aspirate tested positive for CD38, CD 138, CD19 (dim), CD27 (heterogeneous), CD56 (bright), CD81, CD200, CytoLambda. FISH Probe assay on immunomagnetically separated plasma cells from bone marrow aspirate tested positive for IgH-FGFR3 translocation and TP53 deletion seen in $6 \%$ cells. Thus, a diagnosis of multiple myeloma was made (Figure 1).

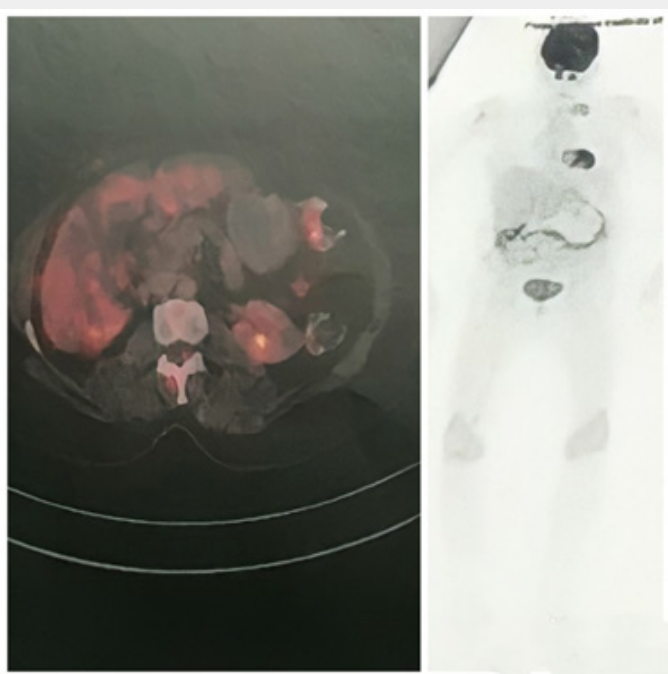

Figure 1: FDG avid and non-avid multiple lytic skeletal lesions as described along with physiological FDG uptake in rest of the visualized organs. 


\section{Cancer Therapy \& Oncology International Journal}

\section{Discussion}

Although patients with clavicular swelling may have a benign aetiology, itis notwise to dismiss this swelling as itmay masquerade serious conditions including neoplasia. It therefore, is imperative to do a thorough clinico-radiological workup. Multiple myelomas are the most common plasma cell neoplasm, characterized by the presence of monoclonal gamma globulins in the serum, referred to as "M" or myeloma proteins [3]. It affects males predominantly and the average age at diagnosis is approximately 60 years [4]. Destructive lesions affect the bones. Patients usually present with complaint of persistent bone pain usually of the lower back or ribs, especially with a history of recurrent fever, fatigue, along with multisystem involvement [5]. Our patient presented with the only complaint of a swelling in the left clavicular region, which over the course of time turned slightly painful.

Radiological examinations in multiple myeloma reveal osteolytic lesions with irregular, non-corticated margins and multiple punched out radiolucencies as is seen in the present case. The diagnosis of multiple myeloma needs a multidisciplinary diagnostic protocol involving investigations of both serum and urine, along with immunoglobulins quantification, as done in our case. This is to be accompanied by cytological examination of bone marrow aspirate and radiological investigations in the form of contrast enhanced CT, PET CT to assess the skeletal involvement. As emphasized by Shah et al. [6] 18F-FDG PET/ CT in myeloma patients is important, as it enables detection of unsuspected sites of bone involvement, which upstages the disease. Treatment of choice in these cases is radiotherapy for the symptomatic lesion followed by chemotherapy [7]. The various chemotherapeutic agents used for treatment are melphalan, vincristine, cyclophosphamide, doxorubicin, and bendamustine in combination with corticosteroids, immunomodulating agents, or proteasome inhibitors. In-depth knowledge of the varied forms of presentation is unquestionably necessary for the clinician as the clinical presentation of the disease does not seem to be influenced to any major extent by the molecular changes.

\section{Conclusion}

Thus, the unsuspected patient who came with a simple, slightly painful left clavicular swelling was finally diagnosed with multiple myeloma. It is difficult to diagnose because other conditions of clavicle also present with same confusing picture. Serum electrophoresis in conjunction with biochemical, pathological, and radiological findings aided in the diagnosis. Thus, a low threshold for suspicion can lead to early diagnosis and initiation of treatment and better survival.

\section{References}

1. Pollard JD, Young GA (1997) Neurology and the bone marrow. J Neurol Neurosurg Psychiatry 63: 706-718.

2. Terpos E, Rahemtullah A (2005) Myeloma. In: Hoffbrand AV, Catovsky D, Tuddenham EGD, editors. Postgraduate haematology. ( $5^{\text {th }}$ edn). Blackwell Publishing, USA, pp. 681-702.

3. Rajkumar V, Dimopoulos M, Palumbo A, Joan Blade, Giampaolo Merlini, et al. (2014) International Myeloma working group updated criteria for the diagnosis of multiple myeloma. The Lancet Oncology 15(12): e538-e548.

4. American Cancer Society (2015) Multiple Myeloma Guidelines.: American Cancer Society, Atlanta, Ga, USA.

5. Obuekwe O N, Nwizu N N, Ojo M A, Ugbodaga P I (2005) Extramedullary presentation of multiple myeloma in the parotid gland as first evidence of the disease-a review with case report. Niger Postgrad Med J 12(1): $45-48$.

6. Shah A, Ali A, Latoo S, Ahmad I (2010) Multiple Myeloma presenting as Gingival mass. J Maxillofac Oral Surg 9(2): 209-212.

7. Kyle RA, Rajkumar SV (2008) Multiple myeloma. Blood 111(6): 29622972.

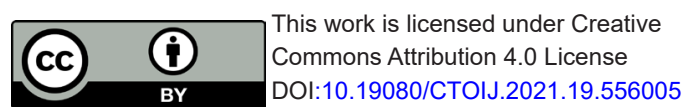

Your next submission with Juniper Publishers will reach you the below assets

- Quality Editorial service

- Swift Peer Review

- Reprints availability

- E-prints Service

- Manuscript Podcast for convenient understanding

- Global attainment for your research

- Manuscript accessibility in different formats

( Pdf, E-pub, Full Text, Audio)

- Unceasing customer service

Track the below URL for one-step submission https://juniperpublishers.com/online-submission.php 